\title{
FURNITURE ACCESSORIES MARKET: AN EXPLORATORY APPROACH AT EUROPEAN MARKET LEVEL
}

\author{
Petrache (Lang) Beatrice Georgeta \\ Universitatea Transilvania din Brasov \\ Marketing Kommunikation Manager bei Simausrom Austria
}

\begin{abstract}
In this article, we aim to identify the views and attitudes of major furniture manufacturers in the European Union on the current situation and trends of the European furniture market and furniture accessories. If for the furniture market has been made more studies and research along the way, for the furniture accessories market this is the first qualitative research to be carried out both at national and European level, a initiative caused by the fact that we have not identified other secondary sources with the exception of data taken from a representative producer, which supplies over $80 \%$ of furniture accessories to major furniture manufacturers in Europe. National and European statistics do not highlight the market for furniture accessories, although in our opinion it is of great importance for the reference industry. In this context, a qualitative research has been carried out whose main objective is to identify the role accessories have in the ergonomics and design of furniture of all categories, regardless of their destination (house, office, hotel, restaurant etc.). The specific objectives of qualitative research are: to identify the opinions and attitudes of the managers of the major furniture manufacturers on the importance of furniture and furniture accessories at the industry level; identifying the views and attitudes of the furniture managers in the furniture industry on the specific market trends in terms of the dynamics of consumer preferences on this market.
\end{abstract}

\section{Keywords}

European furniture market; circular economy; eco-label

\section{JEL Classification}

M31

\section{Introduction}

The European furniture and accessories industry is of particular importance in international trade, providing over one quarter of the world's need in the field and over one million jobs at the 130,000 profile companies. SMEs account for about $70 \%$ of the total added value, of which a significant share is made up of small and microenterprises. In 2015, the European production of the sector amounted to approximately EUR 92 billion, the added value being almost EUR 30 billion, and in the context of the growth of the housing parks, for 2018 it was expected that the furniture would hold between 1.5 and $2 \%$ of the purchasing power of households.

The importance of our research on this market is first demonstrated by the fact that a quarter of the world furniture production comes from the European Union, although this industry is quite fragmented in Europe. As mentioned above, in 2016, there were almost 130,000 furniture manufacturers on the European market, of which about 70\% were SMEs, and the number of employees in production alone amounted to about one million people (Simasrom). Production at 2017 was $€ 86$ billion, of which added value amounted to approximately $€ 31$ billion (Eurostat). Manufacturers of furniture accessories are very small and difficult to identify, and official statistics include these products also in the generic category of "furniture". Germany, Italy, Poland, France and 
Austria are among the top 10 world furniture manufacturers, accounting for over $19 \%$ of world production and $60 \%$ of European production.

In addition, the European furniture market is of great importance from the perspective of the consumption of furniture per capita in Europe, reaching about $2 \%$ of the purchasing power of households (Eurostat). If major world furniture manufacturers are located in several European countries, the main European furniture accessories manufacturer is in Romania (Simausrom) and supplies more than $80 \%$ of the accessories needed by major European manufacturers of furniture. These are the main reasons why I chose the Furniture Market as the research theme in the European Union. The overall objective of the research is to identify the role that accessories have in the ergonomics and design of the furniture of all categories, regardless of their destination. The article has the following parts: summary, introduction, literature review, overview of the market, research methodology, results and discussions, conclusions. Finally, the bibliography used in the research documentation is presented.

\section{Literature review}

In international literature there is an intense concern for studying markets, for preference analysis, but the role and importance of consumer furniture accessories is not highlighted at all. In this context, we will present some aspects of the furniture market at European level, namely a brief analysis of them, as evidenced by various papers and reports.

The nineteenth century brought radical changes throughout Europe, as evidenced by the work of some specialists (Harrsion, 1971). One of the main aspects of the analysis of the literature that is of interest to our research is that furniture manufacturers need to better adapt to the future demands of customers through functionality, aesthetics, material quality and price, all in the context of sustainability (Vink et al, 2012; Vos and der Voordt, 2002).

A concept of relative actuality, the circular economy, also becomes applicable in the furniture industry at European level, with emphasis being placed on the reuse of materials and implicitly on waste minimization, all of which are achievable by designing new products so that a circular pattern can be generated by business in the field (MacArthur Foundation, 2013). As an argument in favor of the existence of circular economy in the furniture sector at European level is the use of chemicals with harmful effects, which if applicable will lead to clean industrial policies in this area.

Another aspect that is linked to the circular economy and which is in the view of researchers, but especially regulating bodies, refers to the eco-labeling system. At European Union level, this system encourages the production of durable, purposefitting furniture, easy to repair and easy to dismantle in separate material streams at the end of its useful life to maximize recycling potential. According to Commission Decision (EU) 2016/1332, the European Commission has extended the scope of ecolabeling criteria by increasing the number of potential products covered, thus creating greater possibilities for the furniture market, although second-hand furniture products are not covered by that decision (JRC, 2015). Regulation (EC) 66/2010 aims to establish an EU-wide voluntary eco-labeling scheme of type ISO, based on scientific and technological criteria, with market orientation, taking into account the most important effects and also by creating the premises of good understanding by consumers. 


\section{Overview of the furniture market}

Global furniture trade accounts for around $1 \%$ of global trade. It grew rapidly by 2008 to US $\$ 117$ billion and declined by $19 \%$ in 2009 . At present, international trade has returned to pre-recession and is expected to grow by about $5 \%$ by 2020. In 2019, Asia and South America will be the regions with the highest demand for furniture, North America will experience modest growth, while in Europe stagnation will continue, with the exception of Eastern Europe. Currently, a quarter of the furniture production in the world is made in the European Union, with the role of Germany, Italy, Poland and France (among the top 10 furniture manufacturers worldwide) being particularly important as they have an aggregate share of $13 \%$ of world production and almost $60 \%$ of total EU production.

According to reports and research in recent years, the European furniture market is recovering slowly and steadily after the crisis triggered in 2008. From the analysis of the statistical data, we find that the share of EU production in the world furniture market is decreasing over the period 2005-2017. A report in 2017 shows that the global furniture industry is worth $\$ 395$ billion, valuation being based on production prices (www.csilmilano.com). The world's largest exporter is China, which has doubled its international sales over the past six years. Still, China's exports fell by $6 \%$, to $\$ 49$ billion in 2016 and $36 \%$ of all furniture exports. At a distance, China is followed by major European producers: Germany (8\% of total exports), Italy (8\%) and Poland (7\%), these European countries registering increases during the analyzed period. In terms of imports, the largest market is the United States (26\% of the total), followed by Germany (11\%), Great Britain (6\%) and France (6\%) (Bosch et al, 2017).

Furniture products record different performances in terms of the competitiveness of EU producers in domestic and foreign markets. Some furniture items are less sensitive to international competition than others for various reasons: price dynamics, design and innovative product content, purchasing process, product characteristics, and other factors linked to the production process.

The EU production position varies significantly between segments, as illustrated in Table 15 . Germany and Italy together account for $40 \%$ of total EU furniture production. The rate increases up to $50 \%$ for kitchen furniture and up to $45 \%$ for office furniture. On the other hand, the share of these countries is reduced to $32 \%$ in the upholstered furniture segment (Poland first, followed by Germany and Italy) and 27\% for mattresses (Eurostat). Regarding the dynamics of imports, the main factors that stimulate imports are:

- Frequent practices by manufacturers of delocalization and outsourcing strategies to allow companies to remain competitive. In a study conducted by CSIL, about $60 \%$ of Western European companies said that some phases of their production processes are outsourced or prefer to buy components from third parties (www.csilmilano.com);

- The availability of raw materials in Asia (rattan, bamboo, sugar cane, etc. for outdoor furniture) has led to a significant increase in imports of such raw materials;

- The penetration of furniture in the European market such as office furniture, is still low, although it has doubled in the last 10 years. China is the most important non-EU supplier in every furniture segment, but its relative weight compared to competitors varies, with the largest share in upholstered segment (accounting for more than $70 \%$ of EU imports from non-EU countries) and in the offices segment $(66 \%)$. Vietnam, the second supplier in terms of finished furniture items, is the second country at a certain distance, but its relative importance has increased in the office segment (Eurostat). 
As regards the materials used, most furniture products are made of wood or wood-based components (except mattresses).

Table 1. Situation regarding the materials used in the manufacture of furniture in the European Union (2017)

\begin{tabular}{|l|c|}
\hline \multicolumn{1}{|c|}{ Materials used } & $\begin{array}{c}\text { Percentage of total } \\
\text { furniture production }\end{array}$ \\
\hline Wood / based on wood furniture & $59 \%$ \\
\hline Metal furniture & $14 \%$ \\
\hline Upholstered furniture (upholstered, mattresses) & $15 \%$ \\
\hline $\begin{array}{l}\text { Furniture made of other materials (plastic, } \\
\text { bamboo, rattan, glass, etc.) }\end{array}$ & $12 \%$ \\
\hline Total & $\mathbf{1 0 0 \%}$ \\
\hline
\end{tabular}

Source: Eurostat

The main factors affecting the competitiveness of furniture manufacturers at European level are: availability of raw materials and skilled labor, investment in machinery and equipment, investment in innovation and design.

\section{Research methodology}

The research conducted and presented in this article is of a qualitative nature and aims at identifying the views and attitudes of major furniture manufacturers in Europe on the current situation and trends of the European furniture market, including furniture accessories. The overall objective of the research is to create a clear picture of the profile of the European furniture consumer with the identification of the role of accessories in the ergonomics and design of furniture of all categories. The specific objectives of qualitative research are:

- Identifying the views and attitudes of the furniture managers in the furniture industry in terms of the dynamics of consumer preferences;

- Identifying the views and attitudes of the major furniture manufacturers on the importance of furniture accessories at the industry level.

The qualitative research method chosen was the interview, and the qualitative research technique was the in-depth interview (Brătucu and Brătucu, 2016), thus wishing to know the opinions of the managers of the furniture companies. The process used in the research was semi-structured interviewing, and the interview guide was used as a tool. The sample comprised 25 managers of major furniture companies from representative countries on the specific market, fulfilling the necessary conditions to achieve the research goal and objectives, respectively having decision-making power at the strategic level. Participation in the interview was conducted on a voluntary basis, using a selection questionnaire in the beginning of which the purpose and objectives of the research were presented. After receiving the approval from the 25 managers, the guide for the in-depth interview was implemented.

The option for the qualitative research method through the interview derives from a series of previous researches carried out on the furniture market and whose results have been validated over time. Thus, Marcus Knauf conducted a market study in which he analyzed the attitudes of German producers and consumers towards lightweight furniture and the use of light wood-based materials in furniture design using a multimodal technique based on the quantitative and qualitative methodologies used in social and economic research (Knauf, 2015). The essential aspect of the research, which served as a benchmark in choosing the research method in this article and gave us confidence in the results, was interviewing German furniture sales representatives and 
observing customers in specialized stores. Research has proven to be an important aspect of our approach: customers consider quality, price and design as central elements in purchasing decisions, and the furniture's weight is in a secondary place. All these three elements (quality, price, design) are significantly outlined in the furniture products by accessories, namely feet, handles and the like, the perception of quality and design being strongly influenced by them.

The production of furniture is also significantly influenced by technologies, and from this point of view there is a strong technological advance, a fact that is also found in the production of furniture accessories. Research over the past 20 years shows that some European countries, although resembling in terms of technologies, differ greatly in organizing the market (Germany and Italy), in particular the size distribution and the organization of retail trade, these differences have an influence on the dynamics of production, prices and exports (Florio et al1998), relevant issues, and now, even under the impact of globalization (Herrigel, 2015).

Technological progress is strongly influenced by information and communication technologies, Internet of Things (IoT) technologies being relevant for the furniture and accessories industry. Thus, according to research carried out on the Italian market, the behavior of manufacturers in the SME category is strongly influenced by the Internet (Balocco et al, 2008). Other significant researches have been made in connection with the ergonomics of the furniture, and the accessories also have a significant, most often defining contribution (Ismail et al, 2017).

For the purpose of this research, we have in mind representative companies in the European furniture industry, with whom Simausrom is doing business, being the supplier of more than $80 \%$ of the accessories these major producers use in their production. Also, the selected sample includes a number of large distributors of furniture in Europe, who buy furniture from major manufacturers as well as from smaller manufacturers.

In the research, it was chosen for the guided sampling, using the quota method, which proved to be appropriate in several previous qualitative research (Silverman, 2013).

The main aspects considered in the sample constitution were, on the one hand, the size and structure of the sample, aspects considered relevant in the literature, even if the opinions of some authors did not excel in preciseness (Golafshani, 2003; Silverman, 2013) and on the other hand they had in view the complex concept of "power of information" (Malterud, 2016), a concept considered by the authors of this research to be the most conducive to reaching the goal and objectives of research, because it covers multiple aspects in interdependence (the type of furniture, the materials from which the accessories are made, etc.).

The topic of the interview was as follows:

Theme 1 . The strengths, weaknesses, opportunities and threats existing on the European furniture market;

Theme 2. Producers' views on the place of furniture accessories within the value chain and the extent to which accessories are among the factors affecting the competitiveness of European furniture manufacturing and distribution companies;

Theme 3. The opinion of managers in the field on the importance of accessories in the purchasing decision;

Theme 4. The specific importance of the presence of furniture accessories in promotional messages.

The obtained answers were recorded and then stored in electronic files. Subsequently, these files were transcribed, the information being processed by the technique known as content analysis. 


\section{Results and discussions}

After the transcription, centralization and processing of the data obtained, the vertical and horizontal analysis was carried out, resulting in the following aspects:

\section{Theme 1. Strengths, weaknesses, opportunities and threats on the European furniture market.}

The views expressed by the interviewed managers were grouped according to similarity for each highlighted issue in order to finally make a SWOT analysis on the furniture market in the EU, which would express the views of the major producers and major traders in Europe.

Thus, the interviewed producers consider that the main strengths are:

- The presence in the European market of all sections of the furniture production value chain. Furniture manufacturers in the EU have a wide variety of inputs, from materials to accessories, a wide network of companies and qualified personnel in all fields of specialization, which gives manufacturers a good ability to adapt to requirements, diffusion and personalization of products.

- High quality raw materials, materials and accessories. The main elements that, in the opinion of interviewed managers, provide additional value in the specific market are wood, leather, metal accessories and finishes.

- Advanced European technology and know-how. The views of all managers converge towards the idea of technology associated with productivity and quality. This observation is valid for materials (leather, wood, fabrics, finishes) and for accessories that are distinctly highlighted and where the requirements are geared to a great variety of materials and shapes / designs. All managers believe that European furniture design is currently unmatched worldwide.

- Existence of other values beyond the price. Furniture production has a great tradition in Europe. According to managers, furniture production, associated with other European cultural heritage, gives European manufacturers a great capacity to incorporate innovation into manufactured products, constantly seeking different styles and fostering the development of skills in the field of creativity, skills that are recognized worldwide.

- Existence of advanced research centers and design schools. European materials and design research are considered as a global opinion maker. Most surveyed producers believe that Europe continues to have key competences in product design, research and innovation, aspects that help them grow within the value chain, increasing their contribution to added value.

- The European market is of considerable size. The furniture market in Europe is mature and extremely dynamic. Managers appreciate that European furniture production covers between 25 and $28 \%$ of world requirements, demonstrating its strength and competitiveness.

- Cooperation and interaction within clusters. Furniture manufacturers surveyed believe that the existence of clusters in the field is beneficial as it makes possible cooperation and interaction across the value chain, with synergic effects being visible at the level of innovation, design and diversification.

The main weaknesses in the European furniture industry and furniture market highlighted in the interviews are:

- The high cost of labor. The furniture sector requires intensive and dedicated work throughout the entire production chain, both in the production of the necessary materials and accessories, in which the incidence of these costs in the production of furniture is relatively high. It has thus become European furniture production to compete in those markets where labor is (still) cheaper.

- Labor is aging. Manufacturers believe this is a weak point that worries them, all the more so as it is seen in the "upstream" of material and accessories 
manufacturers. The problem becomes even more important than that. In their view, there is a lack of ability to bring young workforce into the field and to create effective training facilities.

- Demand still has weak determinants. The residential real estate sector has not yet recovered after the shock caused by the crisis, and those who are currently building practice low prices. In addition, the population tended to spend less on furniture in the last 10 years.

- Protectionist measures in other markets. While the European furniture market is the most open global market, there are protectionist measures in other markets that generate significant distortions in exports.

Opportunities identified in interviews with major EU furniture manufacturers and distributors are:

- New markets. Gulf, China and Russia have become attractive markets, the number of buyers in the "peak" segment is steadily increasing, and local and foreign competition on these markets is still weak. Furniture manufacturers appreciate that potential buyers in those markets will spend more on their furniture than Europeans.

- Changing consumption patterns. In the opinion of manufacturing and marketing companies, consumer patterns are changing, with tendency towards functionality and adaptability to space, to the detriment of sustainability. In terms of accessories, managers are announcing the trend towards matt metal or classic "patina" (rust, wrought iron, bent metal, painted, etc.), somewhat decreasing the intersection for glossy stainless steel or plastic. Manufacturers believe that changing consumer patterns is an option, given their ability to adapt to new requirements through technology, staff and know-how, and traders through capabilities to interact with customers through their deployed CRM programs.

- Exploitation of comparative advantages: competition through quality. The integration of the Western European production system with the central and eastern European production system can lead to increasing the competitiveness of products on the domestic and export markets. In the case of furniture accessories, the major manufacturers buy them almost exclusively from firms in Central and Eastern Europe, Simausrom finds nominated by all 15 producers surveyed.

The threats mentioned in the interviews are:

- Strong competition from Asian countries. Imports from Asian countries are on the rise, with an important share being focused on the segment of average or small buyers.

- Costs and availability of materials and accessories. Fluctuations in raw material prices and availability, including accessories, are seen as threats by furniture manufacturers, whose negative impact is felt at their level.

- Insufficient protection of the intellectual property right. The furniture industry proposes products with rising intangible content, which is mainly found in the brand and design. Mobile furniture manufacturers and traders consider that these elements ensure their competitiveness as they are well protected, which is not the case at present when the specialized institutions formalized these issues very much.

- Evolution of retail markets. Many retailers have invested important amounts for network development, their dominant option being to products that target "medium" and "economic" segments.

- Increased quality of non-European products. This is considered a threat, but it is found that products coming from outside Europe have a growing quality, proof of the technological development of the industry in the exporting 
countries, associated with relatively low prices. This aspect is noticeable both in materials and accessories.

As can be seen, the importance and role that manufacturers and traders attach to accessories as parts of furniture is growing, context in which the next topic of the interview continued to discover how competitiveness affects accessories.

Theme 2. Views on the place of furniture accessories within the value chain and the extent to which accessories are among the factors affecting the competitiveness of European furniture manufacturing and distribution companies.

Producers and traders surveyed consider that furniture accessories are among the essential elements of competitiveness, which results from several aspects. Their weight in the total cost of furniture pieces ranges from 7 to $18 \%$, depending on the type of material, design, level or degree of machining and others.

The share of furniture making materials, as described by the respondents, is shown in Figure 1.

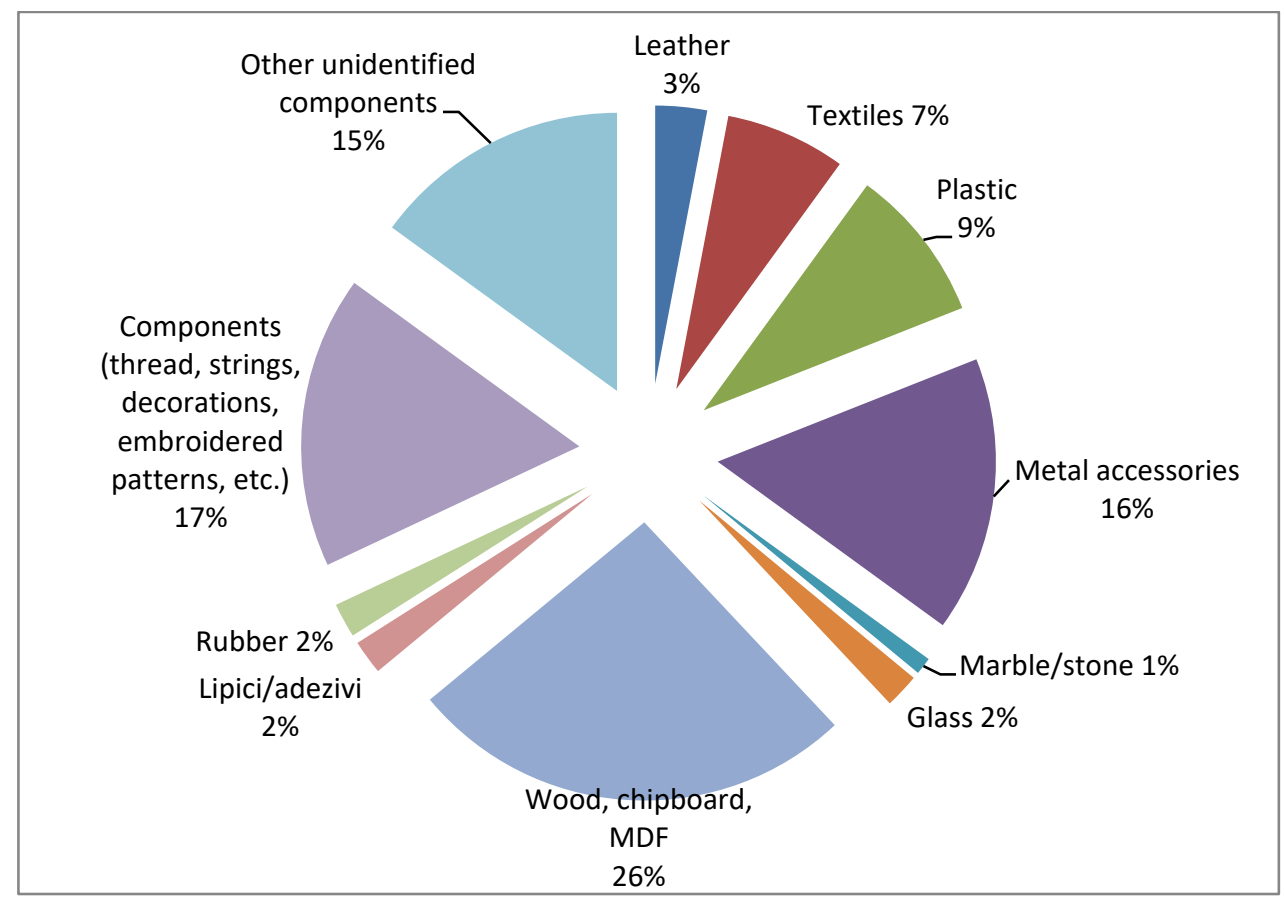

Figure 1. Importance of the elements that make up the pieces of furniture from the perspective of the manufacturers

The main factors that manufacturers and traders consider to be interfering with the analysis of competitiveness in furniture production from the perspective of accessories are:

- The extent to which costs with the necessary accessories affect profitability;

- The availability of accessories to specialized manufacturers;

- The cost and availability of "upstream" specialized workforce at the manufacturers of accessories;

- Investments in machinery and equipment at producer level;

- $\quad$ R \& D, innovation and design at producer level;

- $\quad$ R \& D policies, intellectual and industrial property rights, sustainability, etc.);

- $\quad$ Price trends in the market. 
The place of furniture accessories is shown in Figure 2 and is the result of the views of manfacturers and retailers.

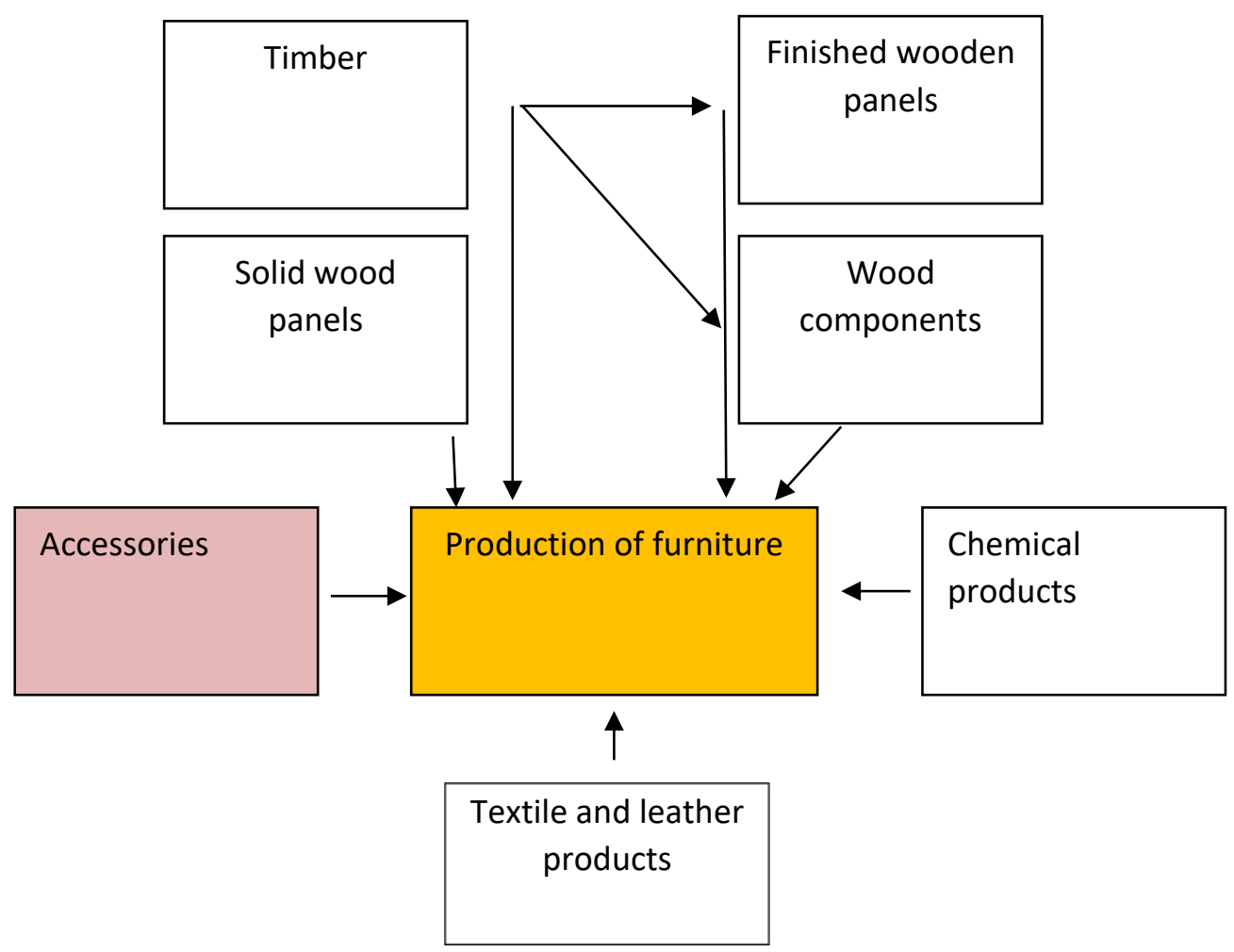

Figure 2. Place of accessories in the value chain in the furniture industry

It turns out that accessories are an important factor for competitiveness, both in terms of costs and the importance of managing the product portfolio.

Theme 3. The opinion of managers in the field on the importance of accessories in the purchasing decision.

Furniture manufacturers and retailers believe that most customers choose the furniture according to the quality of the materials they associate or correlate with each other with the quality of the accessories and the mechanisms that give it ergonomics and functionality.

As can be seen from the SWOT analysis above, buyers are increasingly expressing wishes that metallic elements and mechanisms that ensure functionality are from a particular material painted in a certain color, etc.

Theme 4. The specific importance of the presence of furniture accessories in promotional messages.

Producer and trader's views converge to the idea that mentioning an enhancement aspect in promotional messages is an important element for good product and brand positioning on the market. Ten of the manufacturers and ten traders appreciate that accessories and mechanisms must be components of the psychological axis as they generate the idea of functionality and stability of the furniture, especially when it comes to armchairs, swings, tables, deck chairs and beds. Also, in the case of bathroom and hall furniture, the accessories are of particular importance and they also have ornamental features. 
From the qualitative research carried out through the in-depth interview at the level of some major European furniture manufacturers and traders, we can deduce the quantitative research that will succeed. Thus, we conclude that the main assumptions that will be confirmed or denied by the future quantitative research are:

H1. Consumers differentiate the furniture produced in Europe through quality elements of materials, accessories and design;

H2. European consumers are increasingly aware of the importance of technology and know-how in furniture manufacturing;

H3. European consumers prefer to address specialized retail shops rather than directly to furniture manufacturers;

H4. Non-European furniture is increasingly preferred by buyers on the EU market due to the progress made in quality and design;

H5. European buyers view accessories as essential elements in the decision to choose and buy furniture;

H6. European buyers use the brand as a risk mitigation method before buying;

H7. European buyers increasingly prefer the metallic accessories that are related to the natural environment (rust-like, metal-like, made of metal or blasted metal) instead of glossy metals;

H8. The presence in the promotional messages for furniture of information and images containing accessories is in line with customer expectations

These hypotheses resulting from qualitative research will be taken into account in the design of a future quantitative research, to be validated or invalidated.

\section{Conclusions}

All aspects presented in the above summary underline the role and importance of accessories in furniture products, product management, on the one hand, and purchasing decisions, on the other hand, according to the views expressed by largescale manufacturers and traders at European level.

Thus, among the main strengths they have mentioned in relation to the production and sale of furniture, they refer to the high quality and aesthetics of European products due to $\mathrm{R} \& \mathrm{D}$ activities, manufacturing technologies and the professionalism of manufacturers. The weaknesses identified by manufacturers and traders are the high labor cost, which is relatively aging, the weak determinants of demand and the inadequate protection of intellectual and industrial property rights.

Opportunities identified and presented by the respondents are the existence of new markets, the changing of the consumption patterns and the possibility of adapting the European producers and traders to the new requirements, as well as the real possibility for the producers to exploit the R \& D technologies and resources in order to increase their competitiveness by quality.

The main threats mentioned are: strong Asian competition, the costs and availability of materials and accessories, insufficient protection of intellectual property rights, the evolution of retail markets to weak purchasing power segments and the increase in the quality of non-European products.

The interviewed producers and traders consider furniture accessories to be among the key elements of competitiveness. By invoking production management, it is estimated that the share of accessories in the total cost of furniture is in the range of $7-18 \%$, depending on the type of material, design and level or degree of machining.

Manufacturers and traders believe buyers in the European furniture market are increasingly expressing wishes that metallic elements and mechanisms that ensure functionality are from a certain material, painted in a certain color, etc., unlike previous periods when the problem accessories were at a very low level in the customer's concerns. 
Producer and trader's views converge to the idea that the mention of promotional messages on an accessory item is an important element for a good product and brand positioning on the market as it generates the idea of functionality and stability of the furniture and in the case of bathroom furniture and the hallway, the accessories also have an ornamental role associated with the design.

Considering all the aspects presented above, we believe that the qualitative research achieved has reached its goal and becomes a very good precursor for the quantitative research to be carried out in a specialized market, namely that of furniture accessories at European level.

\section{References}

"THE EU FURNITURE MARKET SITUATION AND A POSSIBLE FURNITURE PRODUCTS INITIATIVE” FINAL REPORT, https://www.csilmilano.com.

Balocco, R., Conforti Andreoni, M. \& Rangone, A., 2008. eBusiness applications in SMEs of Italian industrial districts: the textile and wood/furniture cases. Service Business, November 2008, Volume 2, Issue 4, pp 303-319.

Changing patterns in the European Furniture market (online), http://www.worldfurnitureonline.com/PDF/ WFR-Magazine.pdf)

Ellen MacArthur Foundation. (2013). Towards the circular economy. In: Economic and business rationale for an accelerated transition, Vol. 1. Ellen MacArthur Foundation. Available from: www.ellenmacarthurfoundation.org

Eurostat, www.eurostat.com

Florio, M., Peracchi, F. \& Sckokai, P., 1998. Market Organization and Propagation of Shocks: The Furniture Industry in Germany and Italy. Small Business Economics, Volume 11, Issue 2, pp 169-182.

Golafshani, N., 2003. Understanding Reliability and Validity in Qualitative Research. The Qualitative Report, 8(4), pp. 597-606.

Harrison, M. (1971). People and furniture;: A social background to the English home, Rowman and Littlefield, London.

Herrigel, G., 2015. Globalization and the German industrial production model. Journal for Labour Market Research, Volume 48, Issue 2, pp 133-149

International Organization for Standardization.ISO 14024:2001-Environmental Labels and Declarations-TypeI Environmental Labelling-Principles and Procedures; International Organization for Standardization: Geneva,Switzerland, 2001.

Ismail, S., Rahman, A.A.A., Ismail, A.R., Daud, K.A.M., Khidzir N.Z., 2017. Internet Marketing Strategy for Furniture Industry: A Research Based Ergonomics Sofa. In: Kantola J., Barath T., Nazir S., Andre T. (eds) Advances in Human Factors, Business Management, Training and Education. Advances in Intelligent Systems and Computing, vol 498.

JRC (2015) Revision of GPP and Ecolabel for Furniture - Technical Report 3.0 Working Document for Written Consultation. http://susproc.jrc.ec.europa.eu/furniture/ docs/GPP_Furniture_TR_for_consultation_Oct_2015.pdf

Knauf, M., 2015. Understanding the consumer: Multi-modal market research on consumer attitudes in Germany towards lightweight furniture and lightweight materials in furniture design. European Journal of Wood and Wood Products, Volume 73, Issue 2, pp 259-270

Malterud, K., Siersma, V.D., Guassora, A.D., 2016. Sample Size in Qualitative Interview Studies: Guided by Information Power. Qualitative Health Research, 26(13) pp. 1753-1760. 
McKinsey. (2011). Resource revolution: meeting the world's energy, materials, food, and water needs. McKinsey Global Institute; McKinsey and Company Sustainability, Resource Productivity Practice. Available from: http://www.mckinsey.com/mgi

Silverman, D., 2013. Doing Qualitative Research. London: Sage Publications Ltd.

Tim Bosch, Karin Verploegen, Stefan N. Grösser and Gu van Rhijn (2017), Sustainable Furniture that Grows with End-User, in Stefan N. Grösser Arcadio ReyesLecuona Göran Granholm (Editors): Dynamics of Long-Life Assets From Technology Adaptation to Upgrading the Business Model, Springer Open, pp. 303-326.

Vink, P., Blok, M., Formanoy, M., De Korte, E., \& Groenesteijn, L. (2012). The effects of new ways of work in the Netherlands: National data and a case study. Work, 41(S1), pp. 5081-5085.

Vos, P., \& Van der Voordt, T. (2002). Tomorrow's of fice through today’s eyes: Effects of office innovation in the working environment. Journal of Corporate Real Estate, 4,pp. 48-65.

www.csilmilano.com

www.erostat.com

www.eurostat.com 